\title{
Mathematical Modelling of Malmquist TFP Index as applicable in Banks: A Study of its Origin and Development
}

\author{
Reshampal Kaur ${ }^{1}$, Monika Aggarwal ${ }^{2}$ \\ ${ }^{I}$ (Research Scholar, Panjab Technical University, Jalandhar, India) \\ ${ }^{2}$ (Dr. S RadhakrishnanPost Doctoral Fellow- UGC University Institute of Applied Management Sciences, \\ Panjab University, Chandigarh, India)
}

\begin{abstract}
Productivity of any organisation or Decision making unit (DMU) has always been the topic of acute interest for their managers. Over years measurement of productivity has been a major concern of researchers in India and abroad. Several techniques have been developed and applied in various sectors to see their effectiveness. Popular among these are Regression, input-output analysis, Data envelopment analysis etc. the further advancements in these techniques with the purpose of improving the results has given origin to a new mathematical framework called 'Malmquist Productivity Index'. The present paper endeavours to examine the origin of MPI and discuss the mathematical modelling along with its basic decompositions. It has been observed that MPI has been widely used abroad to measure productivity of banks. So, this paper also attempts to review the existing literature on its application on banking sector.
\end{abstract}

Keywords- bank productivity, data envelopment analysis, malmquist productivity index, total factor productivity.

\section{INTRODUCTION}

Productivity of any organisation or Decision making unit (DMU) has always been the topic of acute interest for their managers. Specially, when it comes to financial institutions like banks, where money matters are managed with a purpose of earning more money as well as with a social responsibility to serve their customers with better service and financial security. So, a detailed understanding of the factors affecting the productivity has always been a priority for the researchers and managers. DMUs need to evaluate their productivity relative to other similar DMUs for two main reasons. One, to find the factors responsible for low productivity. Two, to understand the efficiency relative to more capable DMUs.

The task to measure productivity is very simple if there is only one output as a result of only one input. In such cases, we can measure productivity as output corresponding to each unit of input. Thus firms can be compared on the bases of productivity found. On the contrary, the productivity measurement becomes complex in the case of multiple inputs and outputs. In such cases, productivity is evaluated either as output per worker, or per working hour or per each unit of land. But these measures are only partial measurements and can misinterpret the results. Total factor productivity is comparatively more suitable when to measure and compare the performance of firms, over a period of time. In the case of multiple inputs and outputs, the Total factor productivity can be defined as the ratio of aggregated output to the aggregated inputs.

Malmquist Total Productivity Index: In the year 1953, Swedish economist StenMalmquist introduced a quantity index as the ratios of distance functions [18]. ThenCaves, Christensen and Diewert (CCD) in 1982, definedthe Malmquist total productivity change index (MTFPI). They referred to the original paper of Malmquist (1953) and they named their proposed productivity index in the name of Malmquist [5]. They defined the TFP index using input and output distance functionsas given by Malmquist. This index can be constructed by evaluating the radical distance of the output vectors and input vectors for two time periods, in terms of a referred technology.From that time, this index is considered as the most valuable tool to measureproductivity. 
CCD had introduced Malmquist index as a theoretical index, whereas Fare et al. [9] calculated the MI directly by exploiting the fact that the distance functions on which the MI is based can be calculated by exploiting their relationship to the technical- efficiency measures developed by Michael J. Farrell (1957) [9]. In other words, Fare et al. made use of the connection between Farell's measures of technical efficiency (1957) [11], Data Envelopment Analysis (DEA) by Charnes et al. (1978) and Malmquist productivity index by Caves et al. (1982) to introduce the DEA estimation method for the Malmquist productivity index Färe,Grosskopf, Lindgren and Roos(FGLR model) (1992) had demonstrated that the resulting total factor productivity (TFP) indices could be decomposedinto efficiency-change and technical-change components. Färe, Grosskopf, Norris and Zhang (FGNZ) (1994) further decomposed efficiency change into pure technical efficiency change and changes in scale efficiency, a development that has made the Malmquist index widely popular as an empirical index of productivity change [1].

Malmquist indices of TFP calculate the change in total output relative to inputs[24]. Fare et al.(1994) termed Malmquist productivity index as 'more general' as it allows for inefficient performance and does not presume an underlying functional form for technology. Also, it can be estimated either parametrically or nonparametrically. In parametric approach, distance functions are determined by parametric methods whereas in non-parametric approach, the distance functions are determined by non-parametric methods such as DEA.DEA based MPI can be applied to panel data to measure the productivity changes between two time periods for a given set of DMUs. Moreover, there is no need to work with prices of inputs and outputs as we need in case of Tornqvist and Fisher index.

As the distances can be either output-oriented or input-oriented, the Malmquist TFP indices differ according to the orientation used [7]. The output-oriented productivity measures focus on the maximum level of outputs that can be produced using a given input vector and a given production technology relative to the observed level of outputs. The input-oriented productivity focuses on the level of inputs necessary to produce observed output vectors, under a reference technology. The input and output oriented Malmquist Total Factor Productivity indices result in same numerical measure if the technology referred to exhibits the property of constant returns of scale.

It is more accurate to consider MPI with constant returns to scale as Grifell-Tatje and Lovell [13] proved that Malmquist TFP index may not correctly measure TFP changes when variable returns to scale is assumed. Mohammadreza A. and Mohsen A.[19] stated that The Malmquist Productivity Index is an important and widely used index for measuring relative productivity change of decision making units in multiple time periods. In Banking Sector also, Malmquist TFPI has a large number of applications.

\section{ROL: REVIEW OF LITERATURE}

Neal (2004) examined the differences in efficiency between various types of banks in Australia between 1995 and 1999 using Malmquist Productivity Indexes(MPI). Each bank was treated as having two inputs and three outputs. They found that between 1995 and 1999, TFP grew by an average 7.6\% annually. Asmild, Paradi, Aggarwal and Schaffnit (2004) evaluated the performance of Canadian banking industry, over the twenty years period, 1981-2000. They used Malmquist Indices from DEA scores to calculate productivity changes over time. They showed with an example that the standard decomposition of either the adjacent or the base period Malmquist index into frontier shift and catching up effects was not appropriate when based on DEA window analysis scores.

Ausina, Tatje, Armero and Conesa (2004) analysed the efficiency of 50 Spanish Savings Banks for the period 1992-1998, considering two sub-periods 1992-1995 and 1995-1998, using DEA based Malmquist productivity index, assuming constant returns to scale following Intermediation approach. Three outputs were loans; core deposits: savings, time and transactions deposits; non-traditional output: non-interest income, income from securities. Three inputs were labor: measured as total laborexpenses, Capital: measured as 
physical capital, purchased funds: all deposit categories. They found that about $90 \%$ of firms grew in terms of productivity over the period 1992-1998, only $10 \%$ of firms suffered productivity decline.

Sakar (2006) investigated Turkish commercial banking performance listed in Istanbul Stock Exchange using Malmquist DEA analysis on 11 Turkish banks during ten quarters between 31 dec 2002 to 31 march 2005, with an output orientation, using variable returns to scale. Five inputs 1. Branch number 2. Personnel number per branch 3. Share in total assets 4. Share in total loans 5. Share in total deposits were taken. Five outputs were taken as 1. net profit-losses/total assets (ROA) 2. Net profit-losses/ total shareholder's equity (ROE) 3.Net interest income / total assests 4.Net interest income / total operating income 5.Non- interest income / total assets. Out of total 11 banks, six banks were found to be highly efficient and able to generate maximum output with the given set of inputs, whereas, other banks had lower VRS mean scores over the observation period.

Howcroft and Ataullah (2006) applied a DEA-type Malmquist Total Factor Productivity Index to examine productivity growth in the commercial banking industries of India and Pakistan during 1992-98 using two alternative input-output models namely loan-based model and income-based model taking two sets of outputs and a common set of inputs. In India, the loan-based model revealed an improvement in TFPCH of around 4.6 percent for the entire study period and income-based model showed a comparable improvement of 4.2 percent. Lin, Hsu and Hsiao (2007) investigated the relative efficiency of management and variation of managerial efficiency among 37 domestic banks in Taiwan, using Malmquist Index. Malmquist model indicated that there were 20 banks with an efficiency change less than 1 , which means that managerial efficiency of rest 17 banks had been declining. They considered this study to serve as a good reference for the formulation of a marketing strategy.

Mahesh and Rajiv (2007) examined the changes in the Total Factor Productivity (TFP) of 62 Indian Commercial Banks for the period 1985-2004, by using Malmquist Productivity Index, assuming constant returns to scale, following an output oriented Production approach, considering four different bank groups 1) State Bank of India and Associates (SBI \&A) 2) Nationalized Banks (NB) 3) Private Banks (PB) 4) Foreign Banks. Three outputs were taken as deposits, loan and Investments. Three inputs used were labour, fixed capital and material. They found that on an average there is productivity growth of the total banking sector over the period of study.

Pal, Bishnoi (2009) applied Malmquist TFP indexon panel data of 63 commercial banks operating in India from 1996-2005 with a focus on three major approaches (a) asset approach (b) value added approach and (c) income approach. It was found that national public sector banks had attained the highest growth in overall productivity and its components under the asset and income approaches. The foreign sector banks had performed better than other categories of banks for value addition approach.

Arjomandi, Valadkhani and Harvie (2011), employed bootstrapped Malmquist indices and efficiency scores developed by Simar and Wilson $(1998 \mathrm{~b}, 1999)$ to investigate the effects of government regulation on the performance of the 14 Iranian Banks, over the period 2003-2008 following an intermediation approach, taking three inputs as labour, physical capital and purchased funds \& three outputs as total demand deposits, public sector loans and non-public loans. They found that the industry efficiency level improved over the period 20032006 and deteriorated soon after the regulatory changes were introduced.

Bi, Ding, Luo and Liang (2011) formulated a mixed linear integer programming model based on the introduction of semi-discretionary variables, after classifying the input variables into three groups namely discretionary, non-discretionary and semi-discretionary variables using a DEA based Malmquist productivity index. They illustrated the proposed approach by an application to 17 branches of Bank of China in Anhui Province, which resulted to show a slight decrease in productivity during the year 2007-08 and the productivity change positively during 2008-09 due largely to efficiency increase.

Gitau, Gor (2011) examined the productivity of commercial banks in Kenya in the context of liberalization. They measured the productivity growth and its components from a time series dataset using 
Malmquist index of total factor productivity for a sample of 34 banks for the period 1999-2008, assuming a constant returns to scale. Productivity measured by Malmquist index was found to be equal to 0.973, which means that total productivity decreased by $2.7 \%$. Technological change index was found to be equal to 0.967 and technical efficiency change index was found to be 1.006 .

Sekhri (2011) compared62 banks operating in India, over 2004-09, including 20 public sector banks, 17 private banks and 25 foreign banks, using Malmquist TFP growth measure, taking inputs as interest cost and operating cost. Whereas outputs were taken as loan income, investment income and non- interest income. It was found that the foreign sector banks scored a high TFP mainly because of their high technical efficiency change and the public sector banks performed better than foreign \& private banks in pure efficiency change index.

Liu, Chuang and Huang (2011) measured the operating efficiency and productivity of banking subsidiaries under 11 financial holding companies,between 2003 and 2007 in Taiwan using Malmquist Productivity index(MPI). They combined the GRA, DEA and MPI to create a performance evaluation model suitable in situations where sample sizes are less than thirty. They found that some of banks had inefficiencies due to lack of scale and few others due to lack of technical efficiency.

Casu, Ferrari and Zhao (2013) examined the impact of regulatory reforms on Productivity growth and its components for all commercial Indian Banks, including Foreign, domestic private and state owned Banks, from 1992 to 2009, using Malmquist TFP index and a parametric metafrontierDivisia index. Both DEA and SFA results indicate relatively high levels of efficiency, which worsen after 1998. Results were found to be consistent for state owned and Foreign Banks.

Raphael (2013) used DEA based MPI to measure Productivity change of 21 Tanzanian commercial banks for the period of seven years, 2005-2011, taking inputs as labour, physical capital, operating costs \& deposit. Outputs taken were loan and investments, using an output oriented Intermediation approach. It was found that most of the commercial banks had shown improvement in efficiency by $67 \%$. Also, improvement in technical change, pure technical change and scale efficiency were recorded to be $83 \%, 67 \%$ and $50 \%$ respectively.

Pandey and Singh (2015) attempted to find out the bank productivity in India during the period 20082013, using Malmquist Productivity Index of Total Factor Productivity (TFP) growth into technical change and change in scale efficiency using panel data of 40 banks including 26 public sector banks, 10 private banks and 4 foreign banks, following an intermediation approach, taking two outputs and three input variables. Outputs taken were 1) loans and advances 2) Profit whereas inputs used were 1) Branches 2) Staff 3) deposits. They found that the whole banking system in India had a positive growth during the period of study.

In the next section, we discuss the mathematical formulation of Malmquist TFP index and its decomposition into technical change, change in technical efficiency and change in scale efficiency.

\section{Mathematical Formulation Of MalmQuist Productivity IndeX}

The Malmquist TFP indexis used to measure the change in productivity of a firm over a time period by evaluating the ratio of distance functions in respect of a chosen technology. Let us take the two time periods, $\mathrm{t}_{1}$ and $t_{2}$. In period $t_{1}$, a firm uses input $x_{1}^{t}$ to produce output $y_{1}^{t}$ and in period $t_{2}$, the same firm uses input $x_{2}^{t}$ to produce output $\mathrm{y}_{2}^{\mathrm{t}}$. Let us define the production set at time $\mathrm{t}$, as $\mathrm{S}_{\mathrm{t}}=\left\{\left(\mathrm{x}^{\mathrm{t}}, \mathrm{y}^{\mathrm{t}}\right)\right.$ : $\mathrm{x}^{\mathrm{t}}$ can produce $\left.\mathrm{y}^{\mathrm{t}}\right\}$

Where $\mathrm{x}^{\mathrm{t}}$ is an input vector and $\mathrm{y}^{\mathrm{t}}$ is an output vector such that $x^{t} \in R_{+}^{N}$ and $y^{t} \in R_{+}^{M}$ at time $t$.

Fare et al. (1994) defined an output distance function, for a firm, at time $t_{1}$ as

$$
D^{t_{1}}\left(x^{t_{1}}, y^{t_{1}}\right)=\inf \left\{\theta \in R \mid\left(x^{t_{1}}, \frac{y^{t_{1}}}{\theta}\right) \in S_{t_{1}}\right\} \ldots \ldots \text { (1) }
$$

This distance function is defined as the inverse of Farrel's (1957) technical efficiency measure

$$
D^{t_{1}}\left(x^{t_{1}}, y^{t_{1}}\right)=\left(\operatorname{Sup}\left\{\theta \in R \mid\left(x^{t_{1}}, \theta y^{t_{1}}\right) \in S_{t_{1}}\right\}\right)^{-1}
$$

(1) gives the maximum proportional change in the outputs $y_{1}^{t}$ with the same inputs $x_{1}^{t}$, at time $t_{1}$. 


$$
\text { Also, } \quad D^{t_{2}}\left(x^{t_{2}}, y^{t_{2}}\right)=\inf \left\{\theta \in R \mid\left(x^{t_{2}}, \frac{y^{t_{2}}}{\theta}\right) \in S_{t_{2}}\right\} \ldots \ldots
$$

To compute Malmquist productivity index, we define

$$
D^{t_{1}}\left(x^{t_{2}}, y^{t_{2}}\right)=\inf \left\{\theta \in R \mid\left(x^{t_{2}}, \frac{y^{t_{2}}}{\theta}\right) \in S_{t_{1}}\right\} \ldots \ldots .
$$

Where $D^{t_{1}}\left(x^{t_{2}}, y^{t_{2}}\right)$ gives the maximum proportional change in outputs $\mathrm{y}_{2}^{\mathrm{t}}$ with same inputs $\mathrm{x}_{2}^{\mathrm{t}}$, at time $\mathrm{t}_{1}$

$$
\text { And } D^{t_{2}}\left(x^{t_{1}}, y^{t_{1}}\right)=\inf \left\{\theta \in R \mid\left(x^{t_{1}}, \frac{y^{t_{1}}}{\theta}\right) \in S_{t_{2}}\right\} \ldots \ldots
$$

Where $D^{t_{2}}\left(x^{t_{1}}, y^{t_{1}}\right)$ gives the maximum proportional change in outputs $\mathrm{y}_{1}^{\mathrm{t}}$ with same inputs $\mathrm{x}_{1}^{\mathrm{t}}$, at time $t_{2}$.

MPI defined by Caves, Christensen and Diewert (1982) with reference to the technology of initial period, $\mathrm{t}_{1}$ is

$$
M^{t_{1}}=\frac{D^{t_{1}}\left(x^{t_{2}}, y^{t_{2}}\right)}{D^{t_{1}}\left(x^{t_{1}}, y^{t_{1}}\right)}
$$

However we can also choose the technology of period $t_{2}$ as the reference. The MPI in relation to the technology of final period, $\mathrm{t}_{2}$, can be defined as

$$
M^{t_{2}}=\frac{D^{t_{2}}\left(x^{t_{2}}, y^{t_{2}}\right)}{D^{t_{2}}\left(x^{t_{1}}, y^{t_{1}}\right)}
$$

To avoid an arbitrary choice of reference technology, Fare et al. $(1992,1994)$ defined the Malmquist productivity index of TFP, between periods $\mathrm{t}_{1}$ and $\mathrm{t}_{2} ; \mathrm{t}_{1}<\mathrm{t}_{2}$, as the geometric mean of $M^{t_{1}}$ and $M^{t_{2}}$ (Grosskopf, 1993)

$$
M\left(x^{t_{2}}, y^{t_{2}}, x^{t_{1}}, y^{t_{1}}\right)=\left(\frac{D^{t_{1}}\left(x^{t_{2}}, y^{t_{2}}\right)}{D^{t_{1}}\left(x^{t_{1}, y^{t_{1}}}\right)} \frac{D^{t_{2}}\left(x^{t_{2}}, y^{t_{2}}\right)}{D^{t_{2}}\left(x^{t_{1}, y^{t}}\right)}\right)^{\frac{1}{2}}
$$

Equation (6) can also be written as

$$
M\left(x^{t_{2}}, y^{t_{2}}, x^{t_{1}}, y^{t_{1}}\right)=\frac{D^{t_{2}}\left(x^{t_{2}}, y^{t_{2}}\right)}{D^{t_{1}}\left(x^{t_{1}}, y^{t_{1}}\right)}\left(\frac{D^{t_{1}}\left(x^{t_{2}}, y^{t_{2}}\right)}{D^{t_{2}}\left(x^{t_{2}}, y^{t_{2}}\right)} \frac{D^{t_{1}}\left(x^{t_{1}}, y^{t_{1}}\right)}{D^{t_{2}}\left(x^{t_{1}}, y^{t_{1}}\right)}\right)^{\frac{1}{2}}
$$

Equation (7) is the decomposition of the MPI into product of Change in technical efficiency and technical change. The first term outside the bracket represents the efficiency change component and the second term, inside the bracket, represents the technical change.

Thus for constant returns to scale:

TFP change $=$ Technical change $x$ Technical efficiency change

For variable returns to scale, the component efficiency change can be further decomposed into pure technical efficiency change and scale efficiency change. i.e.

TFP change $=$ Technical change $\mathrm{x}$ Pure technical Efficiency change $\mathrm{x}$ Change in scale efficiency such that

$$
\begin{gathered}
\text { Pure technical efficiency change }=\frac{D_{v}^{t_{2}}\left(x^{t_{2}}, y^{t_{2}}\right)}{D_{v}^{t_{1}}\left(x^{t_{1}}, y^{t_{1}}\right)} \\
\text { Scale ef ficiency change }=\frac{D^{t_{2}}\left(x^{t_{2}}, y^{t_{2}}\right)}{D_{v}^{t_{2}}\left(x^{t_{2}}, y^{t_{2}}\right)} \div \frac{D^{t_{1}}\left(x^{t_{1}}, y^{t_{1}}\right)}{D_{v}^{t_{1}}\left(x^{t_{1}}, y^{t_{1}}\right)}
\end{gathered}
$$

Where the subscript $\mathrm{v}$ indicates the consideration of variable returns to scale.

If the value of $\mathrm{M}$ is greater than 1 , then there has been a positive change in total factor productivity from period $\mathrm{t}_{1}$ to period $\mathrm{t}_{2}$.

\section{CONCLUSION}


Thus it is concluded that measuring efficiency of DMUs based on panel data using Malmquist TFP index has many advantages over the other techniques. If Malmquist TFP index gets a value less than one means there is negative change in productivity and a value of Malmquist TFP more than one indicates positive change in productivity over the period of time. This TFP change can be either due to change in efficiency or due to technical change. A vast application area and an ease of computation are the main reasons behind the popularity of Malmquist TFPI.

\section{REFERENCES}

[1] A. Arjomandi, A. Valadkhani and C. Harvie, "Analysing Productivity Changes Using the Bootstrapped Malmquist Approach: The Case of the Iranian Banking Industry”, Australasian Accounting Business \& Finance Journal, 5(3), 2011.

[2] M. Asmild, J.C. Paradi, V. Aggarwal and C. Schaffnit, "Combining DEA Window Analysis with the Malmquist Index Approach in a Study of the Canadian Banking Industry”,Journal of Productivity Analysis, 21, 2004, 67-89.

[3] M. Alirezaee and M. Tanha, "Extending the Malmquist index to consider the balance factor of decision making units in a productivity analysis", IMA Journal of Management Mathematics, 2015.

[4] G. Bi , J. Ding and Y. Luo, "A new Malmquist productivity index based on semi-discretionary variables with an application to commercial banks of China", International Journal of Information Technology \& Decision Making, 10(4), 2011, 713-730.

[5] D.W. Caves, L.R. Christensen, and W E Diewert, "The economic theory of index numbers and the measurement of input, output, and productivity", Econometrica, 50(6), 1982, 1393-1414.

[6] B. Casu, A.Ferrari and T. Zhao, "Regulatory Reform and Productivity Change in Indian Banking", The Review of Economics and Statistics, 95(3), 2013, 1066-1077.

[7] T. Coelli, D. Rao, C. O'Donnell and G. Battese, "An introduction to efficiency and productivity analysis", Springer( $\left.2^{\text {nd }}\right)$, Science plus Business Media, Inc. 2005.

[8] T. Emili, G. Emili, A. Carmen and C. David, "Sensitivity analysis of efficiency and Malmquist productivity indices: An application to Spanish savings banks", European Journal of Operational Research, 184, 2008, 1062-1084.

[9] R. Fare, S. Grosskopf, B. Lindgren and P. Roos (1989), "Productivity development in Swedish hospitals: A Malmquist Output Index approach", Southern Illinois University, Department of Economics, Discussion Paper no. 89-3. "Productivity Changes in Swedish Pharmacies 1980-1989: A Nonparametric Malmquist Approach." Journal of Productivity Analysis, 1992, 3(3), 85-101: in Charles, A., Cooper, W.W., Le L.S., Data Envelopment Analysis: Theory, Methodology and Applications, (Amsterdam: Kluwer Academic Publisher, 1989).

[10] R. Fare, S. Grosskopf, M. Norris and Z. Zhang, "Productivity growth, technical progress, and efficiency change in industrialized countries", American Economic Review, 84, 1994, 66-83

[11] Farrell and J. Michael, "The Measurement of Productive Efficiency", Journal of the Royal Statistical Society, Series A, General, 120(3), 1957, 253-82.

[12] C.Gitau and S. Gor, "Measuring Factor Productivity of the Banking sector in Kenya", OIDA International Journal of Sustainable Development, 02(12), 2011.

[13] E. G.-Tatje” and C.A.K. Lovell, “A note on the Malmquist productivity index”, Economics Letters, 47, 1995, 169-175.

[14] S. Grosskopf, Some remarks on productivity and its decompositions, 2002.

[15] B. Howcroft and A. Ataullah, "Total Factor Productivity Change: An Examination of the Commercial Banking Industry in India and Pakistan", The Service Industries Journal, 26(2), 2006, 189-202.

[16] Y.H. Lin, G. Hsu and C. Hsiao, "Measuring efficiency of domestic banks in Taiwan: application of data envelopment analysis and Malmquist index", Applied Economics Letters, 14, 2007, 821-827.

[17] C. Liu, L. Chuang and C. Huang, "A Study of Operating Efficiency of Banks under Financial Holding in Taiwan", International Research Journal of Finance and Economic : inMahesh HP and Rajeev M., "Productivity of Indian Commercial Banks in the Pre- and Post-Liberalization Periods", The Icfai Journal of Bank Management, 6(4), 2007.

[18] S.Malmquist, "Index numbers and indifference curves", Trabajos de Estatistica, 4-1, 1953, 209-242.

[19] A. Mohammadreza and A. Mohsen, "Measuring the Effect of the Rules and Regulations on Global Malmquist Index", International Journal of Operations Research and Information Systems, 2(4), 2011, 72-86.

[20] P. Neal, "X-Efficiency and productivity change in Australian Banking", Australian Economics papers, 2004.

[21] P. Pandey and S. Singh, Evaluating the Performance of Commercial Banks in India Using Malmquist and DEA Approach: Some Evidence, The IUP Journal of Bank Management, 14(2), 2015.

[22] V. Pal and N.K. Bishnoi, "Productivity Analysis of Commercial Banks in India, Decision", 36(1), 2009.

[23] G. Raphael,, "A DEA- Based Malmquist Productivity Index approach in assessing performance of commercial banks: Evidence from Tanzania”, European Journal of Business and Management, 5(6), 2013.

[24] B. Sakar, "A Study on Efficiency and Productivity of Turkish Banks in Istanbul Stock Exchange using Malmquist DEA", The Journal of American Academy of Business, 8(2), 2006.

[25] V. Sekhri, "A DEA and Malmquist Index Approach to Measuring Productivity and Efficiency of Banks in India", The IUP Journal of Bank Management, 10(3), 2011 